\title{
Cognitive Apprenticeship Model in The Aesthetics and Ergonomics Material of Entrepreneurship Subject on Students' Creativity in Vocational Higher School
}

\author{
Fajar Arianto ${ }^{\mathrm{a}}$, Ulfatun Nikmah ${ }^{\mathrm{b}}$ \\ AJurusan Teknologi Pendidikan, Fakultas Ilmu Pendidikan, Universitas Negeri Surabaya, Surabaya, \\ Indonesaia.,
}

Fakultas Ilmu Pendidikan, Universitas Negeri Surabaya

Corresponding email: fajararianto@unesa.ac.id

\begin{abstract}
This research aims to know the influence of cognitive apprenticeship model against the creativity of students. The research method used is the true experimental research design in form of matched comparison group. In this design, there are two groups which consist of experimental group and control group. While some of the learning processes done by the students through 5 stages starting from preparation until verification obtained the different result in the process of practical learning activities compare with the traditional learning. Thus, it can be concluded that there is a significant differences on the application of learning model cognitive apprenticeship in the learning process.
\end{abstract}

Keywords: cognitive apprenticeship, creativity

\section{INTRODUCTION}

Vocational education should provide a productive career base that provides backgrounds in knowledge, skills and attitudes, to continue education at every point in individual working life (UNESCO, 2001) ${ }^{[1]}$

Vocational education develops core capabilities of problem solving, interpersonal and communication skills (Skilbeck, Connell, Lowe, \& Tait, 2002) $)^{[2]}$. This suggests that the development of problem solving skills is central to vocational education, as it relates to the world of work. Creativity power is needed by those who graduates from vacational school since they are expected to fill the existing job as a middle-level worker in accordance with competence in the skills program. However, no one knows the fate of others. Even though the researcher's target is the office department students, yet the scholl program to create the creative students in making craft is for all the students and all the majors. Thus, even the students that graduates from offices, they still can get their own workplace when they do not get a job yet. Therefore, it is necessary to equip learners with skills that can take the advantage of the surrounding environment so that they have enough knowledge in entrepreneurship. With the existence of entrepreneurship, students are expected to create their own business instead of seeking a job in certain companies.

Considering the existing problems, it is necessary to conduct a learning model which is relevant to the material and able to support the achievement of learning objectives effectively and efficiently. It is in accordance with the strategy theory, that is, a learning activity must be done by teacher and learners so that the learning objectives can be reached effectively and efficiently (Kemp dalam Rusman, 2012) ${ }^{[3]}$.

Cognitive apprenticeship is a process where learners learn from the more experienced people by means of cognitive and metacognitive skills and processes (Dennen, 2008) $)^{[4]}$. The Cognitive Apprenticeship concept is defined as "learning through cognitive and metacognitive experience, rather than physical, skill and process" (Collins, 1989) $)^{[5]}$. The things involved in cognitive apprenticeship are the demonstration of experts (modeling) and coaching (coaching) in the early stages of learning. Learners are challenged with a more difficult task than they can accomplish and it must be done cooperatively. In other words, at the beginning of the lesson, students are given the more difficult tasks and those tasks cannot be done individually, it should be in a group 
work. By working cooperatively, students will share experiences each other and the communication between them will increase as well.

Cognitive apprenticeship is developed to respond the dichotomy between learning in a class and concrete activities that may arise from professional practice or other real-life situations. A learning process combined with social activities can affect learners' ability. Kaye argues that the development and social processes are urging the nature of their skills and the evolution of skills, the human anatomy, the brain, and the social system all have to go hand in hand (Kaye in Rogoff Barbara, 1990) ${ }^{[6]}$. Collins $(1991)^{[7]}$ suggests the cognitive apprenticeship model has the following methods:

a. Modelling - Demonstrate thinking process

b. Coaching - Helps and supports the cognitive activities of learners needed

c. Scaffolding - support task completion

d. Articulation - Verbalize the results

e. Reflection - analysis and work assessment

f. Exploration - The formation and testing of a particular hypothesis.

\section{METHOD}

The experimental research method is a research method used to find the effect of a particular treatment against others in controlled conditions. In other words, the experimental research consists of independent variable which is manipulated deliberately by the researcher in order to see whether there is or not an influence.

This research is true experimental research design in form of matched group comparison. In this design, there are two groups which conist of experimental group and control group. The first group is given an $\mathrm{X}$ treatment while the other group does not. In this case, the experimental group conists of two classes while the control group consists only one class.

\section{RESULT AND DISCUSSION}

After being given a treatment, that is the application of cognitive apprenticeship in the basic competence of hard craft material products in XI Adm. Office of SMKN 1 Surabaya, showed the results of data obtained through quantitative analysis, it can be categorized in a good value. It means that the learning model cognitive apprenticeship has been implemented in accordance with its method stages. Then, the quantitative data is as follow:

Based on the data analysis on personality creativity result with $\mathrm{dk} \mathrm{m}-1=3-1$ $=2$ and denominator $\mathrm{N}-\mathrm{m}=102-3=99$, it is known that $\mathrm{F}$ count is greater than $\mathrm{F}$ table $(6,289>4,85)$. Thus, it means that the null hypothesis is rejected and the alternate hypothesis is confirmed. Then, it can be stated that the learning process using cognitive apprenticeship can increase students' creativity significantly. While the normality test of the data using Chi Square count smaller than Chi Square table with the ratio $(0.235$ <9.210), hence the distribution of statistical data value can be categorized into normal distribution. The homogeneity ratio with $1 \%$ of error found that the calculation of $\mathrm{F}$ count is smaller than $F_{\text {table }}$ with the ratio (2,258> 2,275). Therefore, it means that the distribution of statistical data value is homogeneity distribution.

From several processes that have been done by students through 5 stages starting from preparation up to verification, it gained a process of learning activity practices that differ from the usual learning. The sequence of those stages is able to bring students into a real-life learning situations. Thus, it can be assumed that the students have achieved the more creative process rather than usual.

Based on the data analysis on the products creativity with $\mathrm{dk} \mathrm{m}-1=3-1=2$ and denominator $\mathrm{Nm}=102-3=99$, it is known that $\mathrm{F}$ count is greater than $\mathrm{F}$ table (7.019) 4.85) which means that the Null Hypothesis is rejected and the Alternate Hypothesis is accepted. While, the normality data test known that the result of Chi Square $_{\text {count }}$ is smaller than Chi Square table with the ratio $(0.314<9.210)$, it means that the statistical data value can be normally distributed. Then the homogeneity test of the data with numerator $\mathrm{dk}=(34-1)$ and denominator $\mathrm{dk}=$ (34-1) with $1 \%$ error rate, known that the result of $F_{\text {count }}$ is smaller than $F_{\text {table }}$ $(1,99<2,275)$, thus the distribution of the statistical data value can be expressed having Homogeneous distribution.

From all above, it means that the null hypothesis is rejected and the alternate hypothesis is confirmed. Thus, the alternate hypothesis that is, " there is significant difference toward the implementation of a 
learning model Cognitive apprenticeship in intrepreneurship subject of aesthetic and ergonomic elements material toward XI graders' creativity in the administrative office department", can be accepted based on the results of the data analysis.

The cognitive apprenticeship model seeks to make visible thinking 'by breaking the process into repeatable steps, emphasizing context, conceptual modelling, and skillgeneralization transfer (Collins, Brown and Holim, 1991 ${ }^{[8]}$. Feedback during the course, to be creatively successful, students need to develop the ability to self-assess their progress critically (Jackson, Sinclair 2006) ${ }^{[9]}$.

In general creativity is defined as person (person), process (process), product (product), and pusher (press) by (Rhodes in Aziz, 2009: 117 ${ }^{[10]}$. Furthermore, it can be described that person means cognitive or personality traits (non-cognitive) inherent in creative people. Process means thinking ability to create new combinations. Product creativity means a new work, useful and understandable by a particular society, and the press is determined by environmental factors both internal and external.

\section{CONCLUSION}

The implementation of a learning model cognitive apprenticeship can be used in a learning process if it meets some principles, those are the learning materials are factual and procedural, then, in the material, it consists of the general techniques, those are task completion, it is needed an approach which can be used in a solution process, it has a purpose to increase creativity in creating a work or practice result, there is such difficulty in the material learning or the application of the material, the materials are practical, the materials are focused in a particular concept, the tasks are realistic, the tasks are used to make students completing the meant assignments, and the learning process is conducted in a collaborative form.

\section{REFERENCES}

[1] UNESCO. (2001). Revised Recommendation concerning Technical and Vocational Education 2001. Paris: UNESCO

[2] Skilbeck, M., Connell, H., Lowe, N., \& Tait, K. (2002). The Vocational Quest: new directions in education and training . New York: Routledge

[3] Rusman. 2012. Learning models. Jakarta : PT. Raja Grafindo Persada

[4] Dennen, Vanessa Paz. 2003. Cognitive Apprenticeship In Educational Practice. America : Florida State University

[5] Collins. A.. Brown, J. S., \& Newman S. E., . 1989. Cognitive Apprenticeship. Hilsdale : Lawrence Erlbaum Associates

[6] Rogoff, Barbara. 1990. Apprenticeship in Thinking. New York : oxford Universsity Press

[7] Collins A., Hawkins, 1., \& Carver, S. M.. 1991. A cognitive apprenticeship for disadvantaged students. America : Jossey B

[8] Collins, A., Brown J.S., \& Holim A.. (1991), Cognitive apprenticeship: Making thinking visible. American Educator. Winter Issue, Washington DC: American Federation of Teachers, pp. 118

[9] Jackson, N. \& Sinclair, C. (2006), Developing student's creativity: searching for an appropriate pedagogy in: Jackson, N., Oliver, M., Shaw, M., \& Wisdom, J. [eds] Developing Creativity in Higher Education: An imaginative Curriculum. Oxford: Routledge

[10] Aziz. 2009. Creative Personal Characteristics and Creative Writing Skills. Journal of Creativity. Vol. 24 (2): page. 116-12. 